$\overline{\text { REVIEW }}$-Current Perspective-

\title{
Neurobiology of the Edg2 Lysophosphatidic Acid Receptor
}

\author{
Akira Yoshida and Hiroshi Ueda* \\ Department of Molecular Pharmacology and Neuroscience, Nagasaki University School of Pharmaceutical Sciences, \\ 1-14 Bunkyo-machi, Nagasaki 852-8521, Japan
}

Received April 16, 2001

\begin{abstract}
Lysophosphatidic acid (LPA, 1-acyl-sn-glycerol-3-phosphate) is a well-known lipid growth factor that is found widely in various tissues including brain and is reported to drive different intracellular signaling pathways. In the nervous system, LPA studies have drawn many neuroscientists' attention because it has some actions related to neurogenesis such as cell rounding and proliferation. Remarkable advances in this field have been obtained along with the discovery of the cDNA clone for its receptor, vzg1/edg2, a member of the seven transmembrane-type edg family. Successive studies have revealed that edg2 activation by LPA mediates several neurobiological actions related to neurogenesis, neuronal excitability and survival activity on developing and postnatal neurons. Here we focused their molecular basis of signaling through $\mathrm{G}$ proteins and in vivo roles of edg2 in such neurobiological events.
\end{abstract}

Keywords: Neurogenesis, Edg, Rho, Lysophosphatidic acid

\section{G-protein-mediated actions of LPA and related lyso- phospholipid}

Lysophosphatidic acid (LPA) as well as sphingosine-1phosphate (S1P) are representative lipid growth factors, and they are biosynthesized de novo mainly through a stimulus-coupled liberation of glycerophospholipids and sphingolipids and subsequent enzymatic conversions (1).

LPA causes various cellular events, including proliferation, changes of cell shapes, motility, membrane excitability and neurotransmitter release $(2-10)$. All these actions are reported to be mostly mediated through various kinds of G proteins $\left(G_{i}, G_{12 / 13}, G_{q / 11}\right)$. In addition to the involvement of several different $\mathrm{G}$ proteins in LPA actions, the discovery of different types of LPA receptors and the presence of S1P, a similar phospholipid, make the understanding of molecular mechanisms of LPA actions more difficult.

\section{Discovery of edg family phospholipid receptors and their signaling through $G$ proteins}

The discovery of the first LPA receptor, vzg1 has contributed to molecular basis of understanding of biological activities of lysophospholipids. Vzg1 has been cloned from the ventricular zone of embryonic cerebral cortex (11). This receptor is highly expressed throughout the neurogenetic

*Corresponding author. FAX: +81-95-844-4248

E-mail: ueda@net.nagasaki-u.ac.jp period. The receptor increased responsiveness to LPA in cell rounding and adenylyl-cyclase inhibition assays when overexpressed in cortical cell lines. The vzg-1 receptor is a member of endothelial cell differentiation gene (edg) family of G-protein-coupled receptors (GPCRs). By homology screening and other approaches totally eight different cDNAs of edg have been discovered (12). The edg family of orphan receptors comprises edg1, edg2/Rec1.3/vzg-1, edg3, edg4, edg5/AGR16/H218, edg6, edg7 and edg8. This family contains LPA receptor and another receptor for S1P that is a lipid mediator structurally related to LPA. According to amino acid sequence homology, ligand specificity and genomic structure, these GPCRs of the edg family are classified into the $\mathrm{LP}_{\mathrm{A}}$-group including edg2, edg4 and edg7 for LPA and $\mathrm{LP}_{\mathrm{B}}$-group including edg1, edg3 and edg5 for S1P (Table 1). Edg6 and edg8 have been recently cloned and characterized as receptors for S1P $(13-15)$. The cannnabinoid $\mathrm{CB}_{1}$ receptor is the non-edg GPCR, though it shares some amino acid homology to the edg receptors. The $\mathrm{CB}_{1}$ receptor has $<30 \%$ amino acid homology with any edg protein (16). Two endogenous lipids, anandamide and 2-arachidonylglycerol, may be the ligands for this drug receptor $(17,18)$. Moreover, a novel GPCR, named PSP24, which does not show significant sequence homology with any member of the edg family, has also been isolated from Xenopus oocytes as a functional receptor for LPA (19). 
Table 1. LPA and S1P receptors in the edg family

\begin{tabular}{llllll}
\hline $\begin{array}{l}\text { Receptor } \\
\text { number }\end{array}$ & Ligand & $\begin{array}{l}\mathrm{LP} \\
\text { designation }\end{array}$ & $\begin{array}{l}\text { Alternative } \\
\text { name }\end{array}$ & $\begin{array}{l}\text { Possible coupled } \\
\mathrm{G}_{\text {proteins }}\end{array}$ & Tissue distribution \\
\hline edg2 & LPA & $\mathrm{LP}_{\mathrm{A} 1}$ & vzg-1, rec1.3 & $\mathrm{G}_{\mathrm{i}}, \mathrm{G}_{\mathrm{o}}, \mathrm{G}_{11}, \mathrm{G}_{12}, \mathrm{G}_{13}$ & $\begin{array}{l}\text { ubiquitous highest abundance in brain } \\
\text { edg4 }\end{array}$ \\
LPA & $\mathrm{LP}_{\mathrm{A} 2}$ & - & $\mathrm{G}_{\mathrm{i}}, \mathrm{G}_{\mathrm{q}}$ & $\begin{array}{l}\text { leukocyte, thymus, spleen, testis, } \\
\text { prostate, pancreas }\end{array}$ \\
edg7 & LPA & $\mathrm{LP}_{\mathrm{A} 3}$ & - & $\mathrm{G}_{\mathrm{q}}$ & heart, pancreas, prostate, testis, lung, ovary \\
edg1 & S1P & $\mathrm{LP}_{\mathrm{B} 1}$ & & $\mathrm{G}_{\mathrm{i}}$ & ubiquitous \\
edg3 & $\mathrm{S} 1 \mathrm{P}$ & $\mathrm{LP}_{\mathrm{B} 2}$ & & $\mathrm{G}_{\mathrm{i}}, \mathrm{G}_{\mathrm{q}}, \mathrm{G}_{13}$ & cardiovascular, leukocyte \\
edg5 & $\mathrm{S} 1 \mathrm{P}$ & $\mathrm{LP}_{\mathrm{B} 3}$ & AGR16, H218 & $\mathrm{G}_{\mathrm{i}}, \mathrm{G}_{\mathrm{q}}, \mathrm{G}_{13}$ & $\begin{array}{l}\text { cardiovascular, central nervous system, } \\
\text { gonadal tissues, placenta }\end{array}$ \\
edg6 & $\mathrm{S} 1 \mathrm{P}, \mathrm{SPC}$ & - & - & $\mathrm{G}_{\mathrm{i}}$ & lymphoid and hematopoietic tissue, lung \\
edg8 & $\mathrm{S} 1 \mathrm{P}$ & - & $\mathrm{nrg}-1$ & $\mathrm{G}_{\mathrm{i}}$ & spleen, brain \\
\hline
\end{tabular}

SPC: sphingosylphosphorylcholine.

Among $\mathrm{LP}_{\mathrm{A}}$-group, the edg2 transcripts were found in almost all human tissues with the highest abundance in the brain (20). In contrast, the edg4 and edg7 transcripts were not found in human tissues as widely as edg2 transcripts and they were almost not detectable in the brain $(20,21)$ (Table 1). Therefore various neuronal effects by LPA may be mostly mediated through edg2 receptor, although it remains to be determined whether a wide variety of LPAactions through various $G$ proteins is simply attributed to the actions through edg2. However, recent studies revealed that edg 2 could functionally activate $G_{i}, G_{0}$ and $G_{11}, G_{12}$ and $\mathrm{G}_{13}$. Accordingly, the possibility that edg2 mediates multiple brain functions can not be excluded.

\section{Neurogenesis and LPA receptor}

As vzg-1, mouse edg2 homologue, is expressed within the embryonic ventricular zone, edg2 is speculated to be both temporally and spatially related to the period of cortical neurogenesis. During early development, cortical cerebral neurons are generated from a discrete proliferative region overlying the cerebral ventricles, the ventricular zone (22). Cortical neuroblasts display a stereotyped change in their morphology that is linked to their proliferation (Fig. 1). During the S-phase of the cell cycle, ventricular zone neuroblasts appear bipolar, with the cell body at the superficial margin of the ventricular zone and with processes oriented towards the ventricular and superficial surfaces of the cerebral wall. With the progression of cell cycle, neuroblasts undergo "interkinetic nuclear migration". During the G2 phase, nucleus descends to the ventricular surface, processes are retracted and finally the cell "round up" (16). After rounding, the cell undergoes mitosis and then regains its bipolar morphology to complete the cell cycle (Fig. 1). There is a possibility that the edg2 receptor might mediate these neurogenic events, since LPA interkinetic nuclear migration

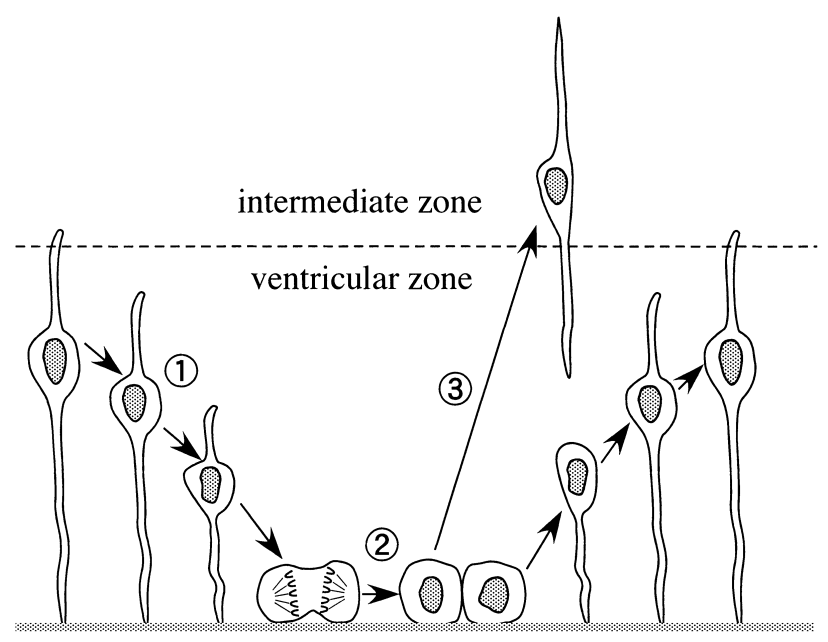

ventricule

(1) process retraction

(2) proliferation

(3) differentiation \& migration

Fig. 1. Interkinetic nuclear migration of neuroblasts in ventricular zone during embryonic neurogenesis.

possesses such morphological and proliferative actions in some cell lines and primary culture neurons.

Rho-mediated signaling in morphological change: LPA stimulates morphological changes via activation of a Rho-dependent pathway that is blocked by botulinum neurotoxin $\mathrm{C} 3$ (BoTxC3) (Fig. 2A). In various cells, Rho is activated through $G_{12}$ and $G_{13}$, which are activated by some receptors, including receptors for thrombin, 
thromboxane $\mathrm{A}_{2}$ and LPA (23-25). LPA activates both $\mathrm{G}_{12}$ and $\mathrm{G}_{13}$, but this activation of $\mathrm{G}_{12}$ was apparently not linked to stress fiber formation (23). On the other hand, there is a report that LPA-induced stress fiber formation is mediated through $\mathrm{G} \alpha_{13}$ and epidermal growth factor (EGF) receptor (26) (Fig. 2A). In that report, an inhibitor for EGF receptor-specific tyrosine kinase or the expression of dominant negative mutant of EGF receptor prevented the LPA-induced stress fiber formation via $\mathrm{G}_{13}$ activation (Fig. 2A).

Neuronal cells also undergo rapid growth cone collapse, neurite retraction and cell rounding in response to LPA $(8,27)$. The LPA-induced neurite retraction could not be prevented by palytoxin (PTX)-treatment or expression of dominant negative Ras (8), suggesting that PTX-sensitive

A. Rho-mediated morphological change

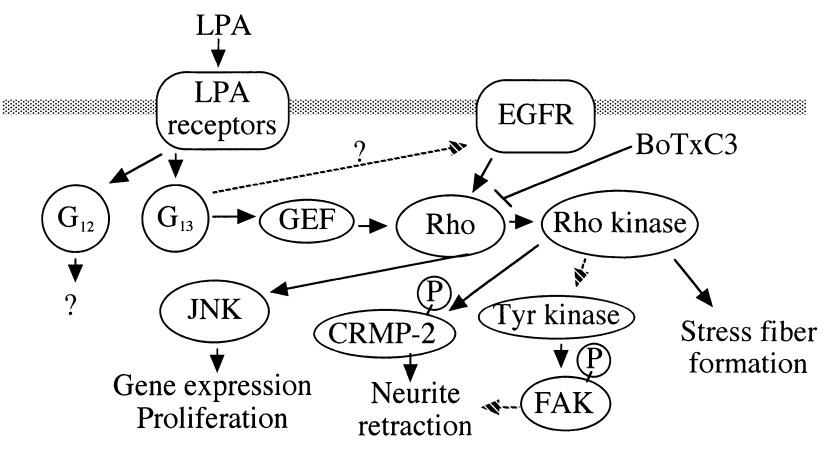

B. $\mathrm{G}_{\mathrm{i} / \mathrm{o}}$-mediated proliferation

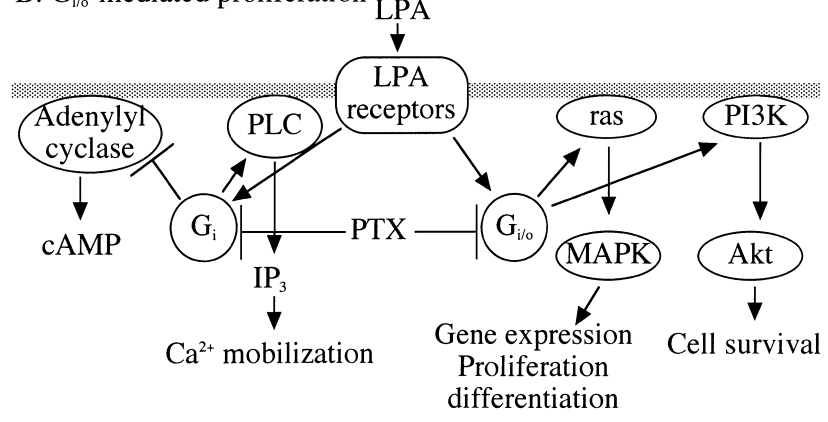

C. $\mathrm{G}_{\mathrm{q} / 1}-$ mediated $\mathrm{Ca}^{2+}$ mobilization

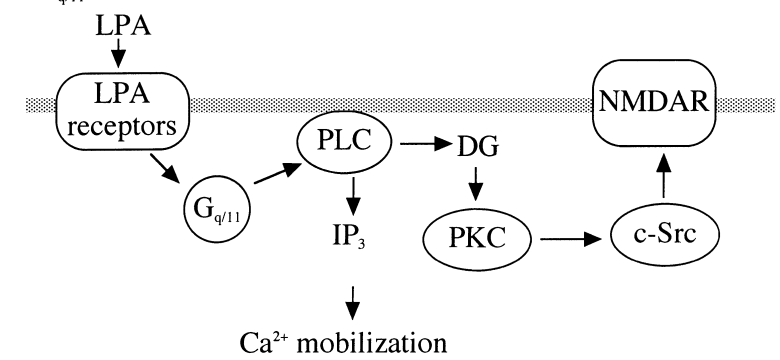

Fig. 2. LPA-induced cellular action and its intracellular signal transduction pathways. A: Rho-mediated morphological changes, B: $\mathrm{G}_{\mathrm{i} / \mathrm{o}}$-mediated proliferation, $\mathrm{C}: \mathrm{G}_{\mathrm{q} / 11}$-mediated $\mathrm{Ca}^{2+}$ mobilization.
G proteins and their downstream mechanisms through the mitogen-activated protein (MAP) kinase pathway are unlikely involved. In N1E-115 neuronal cells, on the other hand, the microinjection of Rho-inactivating BoTxC3 promoted formation of filopodia and lamellipodia, and prevents actomyosin-based neurite retraction and cell rounding induced by LPA (28). In addition, LPA activates Rho kinase to induce growth cone collapse and neurite retraction through a $\mathrm{G}_{13}$-mediated pathway that involves protein-tyrosine kinase activity (29) (Fig. 2A). Recently, the downstream events of Rho kinase involved in the neurite retraction have been reported $(30,31)$. A tyrosine phosphorylation of focal adhesion kinase (FAK) was enhanced during neurite retraction by LPA, which was reduced by $\mathrm{BoTxC} 3$ or Rho kinase inhibitor (30). Another report showed that the Rho kinase phosphorylated collapsin-response-mediator protein-2 (CRMP-2) in chick dorsal root ganglion neurons during LPA-induced growth cone collapse (31). In addition, the overexpression of a negative mutant CRMP-2 inhibited LPA-induced growth cone collapse. These data suggest that LPA-induced Rho kinase activation is involved in neurite retraction through CRMP-2 phosphorylation (Fig. 2A).

Recently it was reported that RhoGEF, a putative GDP /GTP exchange factor, might transduce the $\mathrm{G}_{13}$-signal to Rho. The expression of recombinant RhoGEF induced cell rounding and neurite outgrowth (32), while $\mathrm{G} \alpha_{13}$ directly regulates RhoGEF through a RGS (regulators of G protein signaling)-like domain (33) (Fig. 2A). It is interesting to note that RGSs regulate the LPA signaling through trimeric $G$ protein activation.

Signaling of LPA-induced proliferation: It is well known that the activation of the $\mathrm{G}_{\mathrm{i}}$-Ras-MAP kinase pathway mediates transcriptional activation of immediate-early genes, subsequent DNA synthesis and cell proliferation $(34-37)$. This mechanism is also reported to be involved in LPA-induced cell-proliferation (10). Recent studies demonstrated that LPA-induced activation of MAP kinases (Erk1 and Erk2) through $\mathrm{G}_{\mathrm{i}}$ signaling is negatively regulated by some RGSs (38). Recently, a Grb2-associated binder1 (Gab1) is reported to be involved in Erk2 activation by LPA through edg2 (39), although the involvement of $\mathrm{G}_{\mathrm{i}}$ remains unclear.

Several studies demonstrated that edg2 functionally couples to $\mathrm{G}_{\mathrm{i}}$. This fact indicates that LPA-mediated activation of edg2 may contribute to the proliferation in neurogenesis (Fig. 2B). We reported that edg2 functionally couples to $G_{i 1}$ as well as $G_{o A}$ and $G_{11}$, but not $G_{s}$ in reconstitution experiments measuring $\left[{ }^{35} \mathrm{~S}\right] \mathrm{GTP} \gamma \mathrm{S}$ binding in the baculovirus expression system (40). From the Scatchard Plot analysis, we found that edg2 has basal activity to stimulate $\mathrm{G}_{\mathrm{i} 1}$, but not $\mathrm{G}_{\mathrm{oA}}$ without stimulation by LPA. It is interesting to note that the high level expression of edg2 
specific for the early stage of neural development may itself stimulate neural proliferation.

On the other hand, LPA-induced cell proliferation through $\mathrm{G} \alpha_{12}$ and $\mathrm{G} \alpha_{13}$ has been also reported. In this mechanism, Rho activation is involved in Jun $\mathrm{NH}_{2}$-terminal kinase/stress-activated protein kinase (JNK) pathway (41, 42) (Fig. 2A).

Other mechanisms in neurogenesis: Although it is evident that LPA may be involved in the morphological changes and mitogenesis in neurogenesis, it has been unclear whether LPA directly stimulates the neuroblast during neurogenesis. A recent report showed that neuroblasts can respond to LPA application with multiple ionic conductance changes (43). The whole-cell patch clamp technique revealed that some cortical cells at embryonic day 11 responded only to LPA but not to GABA or L-glutamate. These LPA-responsible cells were then found to be nestinpositive and to incorporate BrdU.

\section{Roles of edg2 in various functions in postnatal ner- vous system}

Although the gene expression of edg 2 in the postnatal nervous system is quite low, compared to the case with developing brain, there are some intriguing reports that LPA affects mature neurons. LPA can regulate NMDAreceptor function indirectly through a G-protein-coupled receptor activation and $\mathrm{PKC}$-dependent activation of the non-receptor tyrosine kinase (Src) signaling cascade (44) (Fig. 2C). LPA caused growth cone collapse in chick dorsal root ganglion neurons, retinal neurons, and sympathetic ganglion cells as well as neuronal cell lines (45). Moreover, LPA-treatment of rat hippocampal neurons resulted in necrosis and apoptosis at high and low concentration, respectively (46).

LPA receptor edg2 is expressed in oligodendrocytes and Schwann cells (SCs) during development (47), suggesting an influence of LPA on the myelinating cells. LPA shows a potent survival activity for cultured neonatal SCs (48). Pharmacological studies revealed that the survival activity by LPA is mediated by $\mathrm{G}_{i}$, phospholipase $\mathrm{C}$ (PLC) and Akt pathway (Fig. 2B). Overexpression of edg2 decreased SC apoptosis even in the absence of LPA, although it is unclear whether endogenous LPA is involved there.

Recently, we found nociceptive actions of LPA in the peripheral flexor test in adult mice (49). These actions were proved to be mediated through an action on nociceptor endings of primary afferent neurons, by the experiment using antisence oligodeoxynucleotide. In addition to it, the activation of PTX-sensitive $G$ proteins and substance $P$ (SP) release from nociceptor endings were found to be involved in the in vivo signaling of LPA-nociception (Fig. 3). Series of our extensive studies strongly suggested that $\mathrm{G}_{\mathrm{i}}$-coupled receptor-induced nociception is attributed

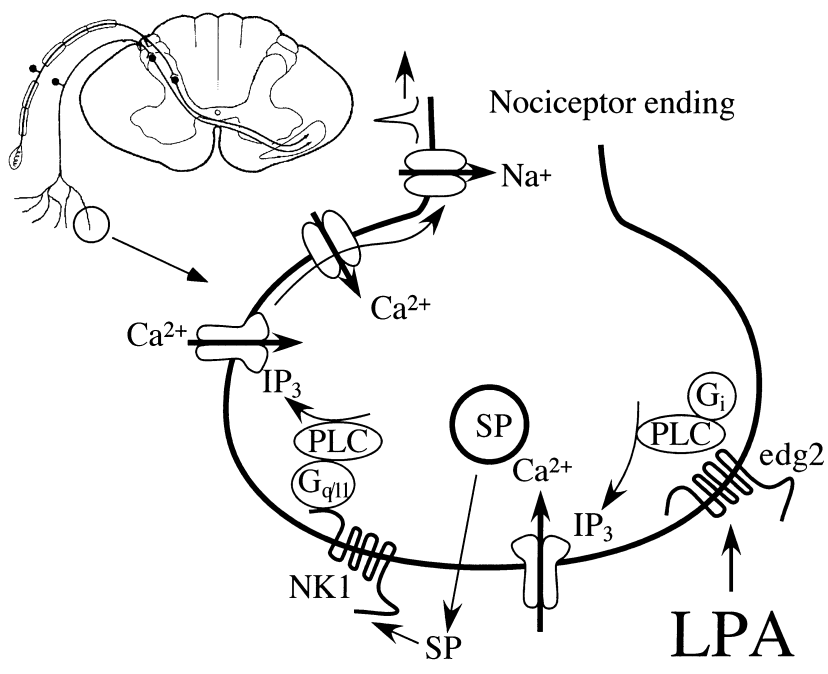

Fig. 3. Molecular mechanisms of LPA-induced nociception at peripheral nerve ending. NK1: neurokinin 1 receptor.

to the SP release from nociceptor endings of polymodal C-fiber by activation of inositol 1,4,5-trisphosphate $\left(\mathrm{IP}_{3}\right)$ induced $\mathrm{Ca}^{2+}$ mobilization (50).

\section{Perspective}

Accumulating evidence suggesting that edg2 LPA receptor expressed in the early stage of neuronal development may play an important role in embryonic neurogenesis. In adult brain, on the other hand, the receptor becomes more expressed in glia cells. Through a regulation of proliferation and differentiation of neurons and glia cells, the edg2 LPA receptor may be involved in the neuronal network maintenance. To study whether this receptor is involved in the adult brain neurogenesis would be also an interesting subject. Further studies using conditional knock-out mice would provide the answer to this question.

\section{REFERENCES}

1 Goetzl EJ and An S: Diversity of cellular receptors and functions for the lysophospholipid growth factors lysophosphatidic acid and sphingosine 1-phosphate. Faseb J 12, 1589 - 1598 (1998)

2 Dixon RJ, Young K and Brunskill NJ: Lysophosphatidic acidinduced calcium mobilization and proliferation in kidney proximal tubular cells. Am J Physiol 276, F191 - F198 (1999)

3 Moolenaar WH, Kranenburg O, Postma FR and Zondag GC: Lysophosphatidic acid: G-protein signalling and cellular responses. Curr Opin Cell Biol 9, 168 - 173 (1997)

4 Plevin R, MacNulty EE, Palmer S and Wakelam MJ: Differences in the regulation of endothelin-1- and lysophosphatidic-acidstimulated Ins(1,4,5)P3 formation in rat-1 fibroblasts. Biochem $\mathrm{J}$ 280, 609 - 615 (1991)

5 Shiono S, Kawamoto K, Yoshida N, Kondo T and Inagami T: Neurotransmitter release from lysophosphatidic acid stimulated PC12 cells: involvement of lysophosphatidic acid receptors. 
Biochem Biophys Res Commun 193, 667 - 673 (1993)

6 Takemura H, Imoto K, Sakano S, Kaneko M and Ohshika H: Lysophosphatidic acid-sensitive intracellular $\mathrm{Ca}^{2+}$ store does not regulate $\mathrm{Ca}^{2+}$ entry at plasma membrane in Jurkat human Tcells. Biochem J 319, 393 - 397 (1996)

7 Tigyi G, Dyer DL and Miledi R: Lysophosphatidic acid possesses dual action in cell proliferation. Proc Natl Acad Sci USA 91, 1908 - 1912 (1994)

8 Tigyi G, Fischer DJ, Sebok A, Marshall F, Dyer DL and Miledi $\mathrm{R}$ : Lysophosphatidic acid-induced neurite retraction in $\mathrm{PC} 12$ cells: neurite-protective effects of cyclic AMP signaling. J Neurochem 66, 549 - 558 (1996)

9 Tigyi G, Fischer DJ, Sebok A, Yang C, Dyer DL and Miledi R: Lysophosphatidic acid-induced neurite retraction in PC12 cells: control by phosphoinositide- $\mathrm{Ca}^{2+}$ signaling and Rho. J Neurochem 66, 537 - 548 (1996)

10 van Corven EJ, Groenink A, Jalink K, Eichholtz T and Moolenaar WH: Lysophosphatidate-induced cell proliferation: identification and dissection of signaling pathways mediated by G proteins. Cell 59, 45 - 54 (1989)

11 Hecht JH, Weiner JA, Post SR and Chun J: Ventricular zone gene-1 (vzg-1) encodes a lysophosphatidic acid receptor expressed in neurogenic regions of the developing cerebral cortex. J Cell Biol 135, 1071 - 1083 (1996)

12 Lynch KR and Im I: Life on the edg. Trends Pharmacol Sci 20, 473 - 475 (1999)

13 Pyne S and Pyne NJ: Sphingosine 1-phosphate signalling in mammalian cells. Biochem J 349, 385 - 402 (2000)

14 Yamazaki Y, Kon J, Sato K, Tomura H, Sato M, Yoneya T, Okazaki H, Okajima F and Ohta H: Edg-6 as a putative sphingosine 1-phosphate receptor coupling to $\mathrm{Ca}^{2+}$ signaling pathway. Biochem Biophys Res Commun 268, 583 - 589 (2000)

15 Im DS, Heise CE, Ancellin N, O'Dowd BF, Shei GJ, Heavens RP, Rigby MR, Hla T, Mandala S, McAllister G, George SR and Lynch KR: Characterization of a novel sphingosine 1-phosphate receptor, Edg-8. J Biol Chem 275, 14281 - 14286 (2000)

16 Seymour RM and Berry M: Scanning and transmission electron microscope studies of interkinetic nuclear migration in the cerebral vesicles of the rat. J Comp Neurol 160, 105-125 (1975)

17 Devane WA, Hanus L, Breuer A, Pertwee RG, Stevenson LA, Griffin G, Gibson D, Mandelbaum A, Etinger A and Mechoulam $\mathrm{R}$ : Isolation and structure of a brain constituent that binds to the cannabinoid receptor. Science 258, 1946 - 1949 (1992)

18 Stella N, Schweitzer P and Piomelli D: A second endogenous cannabinoid that modulates long-term potentiation. Nature $\mathbf{3 8 8}$, $773-778$ (1997)

19 Guo Z, Liliom K, Fischer DJ, Bathurst IC, Tomei LD, Kiefer $\mathrm{MC}$ and Tigyi G: Molecular cloning of a high-affinity receptor for the growth factor-like lipid mediator lysophosphatidic acid from Xenopus oocytes. Proc Natl Acad Sci USA 93, 14367 14372 (1996)

20 An S, Bleu T, Hallmark OG and Goetzl EJ: Characterization of a novel subtype of human $\mathrm{G}$ protein-coupled receptor for lysophosphatidic acid. J Biol Chem 273, 7906 - 7910 (1998)

21 Bandoh K, Aoki J, Hosono H, Kobayashi S, Kobayashi T, Murakami-Murofushi K, Tsujimoto $\mathrm{M}$, Arai $\mathrm{H}$ and Inoue $\mathrm{K}$ : Molecular cloning and characterization of a novel human Gprotein-coupled receptor, EDG7, for lysophosphatidic acid. J Biol Chem 274, 27776 - 27785 (1999)

22 Boulder Committee: Embryonic vertebrate central nervous system: revised terminology. Anat Rec 166, $257-261$ (1970)

23 Gohla A, Harhammer R and Schultz G: The G-protein $\mathrm{G}_{13}$ but not $\mathrm{G}_{12}$ mediates signaling from lysophosphatidic acid receptor via epidermal growth factor receptor to Rho. J Biol Chem 273, 4653 - 4659 (1998)

24 Laugwitz KL, Allgeier A, Offermanns S, Spicher K, Van Sande J, Dumont JE and Schultz G: The human thyrotropin receptor: a heptahelical receptor capable of stimulating members of all four G protein families. Proc Natl Acad Sci USA 93, 116- 120 (1996)

25 Offermanns S, Laugwitz KL, Spicher $\mathrm{K}$ and Schultz G: $G$ proteins of the $G_{12}$ family are activated via thromboxane $A_{2}$ and thrombin receptors in human platelets. Proc Natl Acad Sci USA 91, $504-508$ (1994)

26 Gohla A, Offermanns S, Wilkie TM and Schultz G: Differential involvement of $\mathrm{G} \alpha_{12}$ and $\mathrm{G} \alpha_{13}$ in receptor-mediated stress fiber formation. J Biol Chem 274, 17901 - 17907 (1999)

27 Jalink K, van Corven EJ, Hengeveld T, Morii N, Narumiya $\mathrm{S}$ and Moolenaar WH: Inhibition of lysophosphatidate- and thrombin-induced neurite retraction and neuronal cell rounding by ADP ribosylation of the small GTP-binding protein Rho. J Cell Biol 126, 801 - 810 (1994)

28 Kozma R, Sarner S, Ahmed S and Lim L: Rho family GTPases and neuronal growth cone remodelling: relationship between increased complexity induced by $\mathrm{Cdc} 42 \mathrm{Hs}$, Rac1, and acetylcholine and collapse induced by RhoA and lysophosphatidic acid. Mol Cell Biol 17, 1201 - 1211 (1997)

29 Kranenburg O, Poland M, van Horck FP, Drechsel D, Hall A and Moolenaar WH: Activation of RhoA by lysophosphatidic acid and $\mathrm{G} \alpha_{12 / 13}$ subunits in neuronal cells: induction of neurite retraction. Mol Biol Cell 10, 1851 - 1857 (1999)

30 Arimura N, Inagaki N, Chihara K, Menager C, Nakamura N, Amano M, Iwamatsu A, Goshima Y and Kaibuchi K: Phosphorylation of collapsin response mediator protein-2 by Rhokinase: evidence for two separate signaling pathways for growth cone collapse. J Biol Chem 275, 23973 - 23980 (2000)

31 Linseman DA, Hofmann F and Fisher SK: A role for the small molecular weight GTPases, Rho and $\mathrm{Cdc} 42$, in muscarinic receptor signaling to focal adhesion kinase. J Neurochem 74, $2010-2020$ (2000)

32 Gebbink MF, Kranenburg O, Poland M, van Horck FP, Houssa $\mathrm{B}$ and Moolenaar WH: Identification of a novel, putative Rho-specific GDP/GTP exchange factor and a RhoA-binding protein: control of neuronal morphology. J Cell Biol 137, $1603-$ 1613 (1997)

33 Mao J, Yuan H, Xie W and Wu D: Guanine nucleotide exchange factor GEF115 specifically mediates activation of Rho and serum response factor by the $\mathrm{G}$ protein $\alpha$ subunit $\mathrm{G} \alpha_{13}$. Proc Natl Acad Sci USA 95, 12973 - 12976 (1998)

34 Chuprun JK, Raymond JR and Blackshear PJ: The heterotrimeric G protein $\mathrm{G} \alpha_{\mathrm{i} 2}$ mediates lysophosphatidic acid-stimulated induction of the c-fos gene in mouse fibroblasts. J Biol Chem 272, 773 - 781 (1997)

35 Kumagai N, Morii N, Fujisawa K, Yoshimasa T, Nakao K and Narumiya S: Lysophosphatidic acid induces tyrosine phosphorylation and activation of MAP-kinase and focal adhesion kinase in cultured Swiss 3 T3 cells. FEBS Lett 329, 273 - 276 (1993)

36 Seewald S, Sachinidis A, Dusing R, Ko Y, Seul C, Epping P and Vetter H: Lysophosphatidic acid and intracellular signalling in vascular smooth muscle cells. Atherosclerosis 130, 121-131 (1997) 
37 van Corven EJ, Hordijk PL, Medema RH, Bos JL and Moolenaar WH: Pertussis toxin-sensitive activation of $\mathrm{p} 21$ ras by G proteincoupled receptor agonists in fibroblasts. Proc Natl Acad Sci USA 90, 1257 - 1261 (1993)

38 Chatterjee TK, Eapen AK and Fisher RA: A truncated form of RGS3 negatively regulates G protein-coupled receptor stimulation of adenylyl cyclase and phosphoinositide phospholipase C. J Biol Chem 272, 15481 - 15487 (1997)

39 Cunnick JM, Dorsey JF, Munoz-Antonia T, Mei L and Wu J: Requirement of SHP2 binding to Grb2-associated binder-1 for mitogen-activated protein kinase activation in response to lysophosphatidic acid and epidermal growth factor. J Biol Chem 275, 13842 - 13848 (2000)

40 Yoshida A and Ueda $\mathrm{H}$ : Activation of $\mathrm{G}_{\mathrm{i} 1}$ by lysophosphatidic acid receptor without ligand in the baculovirus expression system. Biochem Biophys Res Commun 259, 78 - 84 (1999)

41 Prasad MV, Dermott JM, Heasley LE, Johnson GL and Dhanasekaran N: Activation of Jun kinase/stress-activated protein kinase by GTPase-deficient mutants of $\mathrm{G} \alpha 12$ and $\mathrm{G} \alpha 13$. J Biol Chem 270, 18655 - 18659 (1995)

42 Olson MF, Ashworth A and Hall A: An essential role for Rho, Rac, and Cdc42 GTPases in cell cycle progression through G1. Science 269, 1270 - 1272 (1995)

43 Dubin AE, Bahnson T, Weiner JA, Fukushima N and Chun J: Lysophosphatidic acid stimulates neurotransmitter-like conductance changes that precede GABA and L-glutamate in early, presumptive cortical neuroblasts. J Neurosci 19, $1371-1381$ (1999)

44 Lu WY, Xiong ZG, Lei S, Orser BA, Dudek E, Browning MD and MacDonald JF: G-protein-coupled receptors act via protein kinase $\mathrm{C}$ and Src to regulate NMDA receptors. Nat Neurosci 2, 331 - 338 (1999)

45 Saito S: Effects of lysophosphatidic acid on primary cultured chick neurons. Neurosci Lett 229, 73 - 76 (1997)

46 Steiner MR, Holtsberg FW, Keller JN, Mattson MP and Steiner SM: Lysophosphatidic acid induction of neuronal apoptosis and necrosis. Ann NY Acad Sci 905, 132 - 141 (2000)

47 Weiner JA, Hecht JH and Chun J: Lysophosphatidic acid receptor gene vzg-1/lpA1/edg-2 is expressed by mature oligodendrocytes during myelination in the postnatal murine brain. J Comp Neurol 398, 587 - 598 (1998)

48 Weiner JA and Chun J: Schwann cell survival mediated by the signaling phospholipid lysophosphatidic acid. Proc Natl Acad Sci USA 96, 5233 - 5238 (1999)

49 Renback K, Inoue $\mathrm{M}$ and Ueda $\mathrm{H}$ : Lysophosphatidic acidinduced, pertussis toxin-sensitive nociception through a substance $P$ release from peripheral nerve endings in mice. Neurosci Lett 270, 59 - 61 (1999)

50 Renback K, Inoue M, Yoshida A, Nyberg F and Ueda H: Vzg-1 /lysophosphatidic acid-receptor involved in peripheral pain transmission. Brain Res Mol Brain Res 75, 350 - 354 (2000) 